ZIBELINE INTTERNATIIONAL

ISSN: 2521-0890 (Print)

ISSN: 2521-0491 (Online)

CODEN : GBEEB6

\title{
TIDE-DOMINATED SHORELINE DEPOSITS IN THE NEOGEN SEQUENCE AT SEBATIK ISLAND, MALAYSIA
}

\author{
Muhammad Umar Sarimal*, Sanudin Hj. Tahir \\ Faculty of Science and Natural Resources, Universiti Malaysia Sabah \\ *Corresponding Author Email: muhd_umar@jmg.gov.my
}

This is an open access article distributed under the Creative Commons Attribution License, which permits unrestricted use, distribution, and reproduction in any medium, provided the original work is properly cited.

\section{ARTICLE DETAILS}

\section{Article History:}

Received 26 June 2018 Accepted 2 July 2018 Available online 1 August 2018

\section{ABSTRACT}

Sebatik Island belongs to two countries; Malaysia (northwest) and Indonesia (southeast). The study only involved Malaysia's area, covering an area about $200 \mathrm{~km} 2$. The area of study comprised of Sebatik Sandstone-Shale Member from Kalumpang Formation; is part of the Neogene sequence located in the northern part of the Tarakan Basin. The main objective of this study is to analyze the sedimentary facies, and then to interpret the paleoenvironment in the study area. There has been no such study ever conducted by any researcher in Sebatik Island, Malaysia. This study was carried out through systematic characterization of sedimentary structure parameters on rock outcrops in the field based on sedimentological methods. Regarding on that characterization, several facies had been identified; amongst them namely heterolithic facies that was divided into three subfacies; lenticular bedding, wavy bedding and flaser bedding. These subfacies are combined and linked into one facies association that describe of the shoreline environments. It is formed through drag and drop processes dominated by the tides influence. The discovery on Sebatik Island, Malaysia is in line with the setting of Meliat Formation, Indonesia.

\section{KEYWORDS}

Facies analysis, sedimentary structures, heterolithic, tide, shoreline.

\section{INTRODUCTION}

Sebatik Island located in the south of Sabah, is an area owned by two countries namely, Malaysia and Indonesia (Figure 1). Many outcrops of rocks are found at the Kg. Mentadak Baru-Kg. Bergosong road, Heng Ann Farm, Wallace Bay Post, Malaysia-Indonesia border, Kg. Bergosong-Kg. Mentadak Lama road, Heng Ann-Post Wallace, Heng Ann Farm-Kg. Simpang Tiga road, and along the Sebatik Anticline axis. The research on the sedimentary facies was the first to be carried out on Sebatik Island, Malaysia. This paper focuses on the sedimentological aspects of Sandstone-Shale Sebatik Member, Kalumpang Formation in Sebatik Island, Malaysia which involves mapping, characterization and analysis of sedimentary facies to determine the process that occurred during the deposition of Sandstone-Shale Sebatik Member. The previous established geological map in the study area shown in Figure 2.

\section{GEOLOGICAL SETTING}

The Kalumpang Formation was introduced by a researcher; consisting of a layer of mudstone and sandstone, conglomerate, limestone, marl, rijang, and volcanic rocks [1]. He suggested that the age of the Kalumpang Formation range from Late Oligocene to Late Miocene and the age has been confirmed [1]. However, the age of Kalumpang Formation was Early Miocene to Middle Miocene. Some researchers propose an age for Sipit Limestone Member, Kalumpang Formation based on the discovery of larger benthic foraminifera, Aquitanian to Serravallian (Early Miocene Middle Miocene) [2]. Meanwhile, other group of researchers had been studying about Neogene arc-continent collision in Sabah and they suggested the age of volcanic rocks (andesite) on the Semporna Peninsula was $12.92 \pm 0.65 \mathrm{Ma}$, based on Potassium-Argon (K-Ar) dating (sample no.: S 138-1) [3]. The formation lies on the Kalumpang River, Binuang Valley, Sebatik Island and the Semporna Peninsula. The Kalumpang Formation is divided into four rock units, namely: Sebatik sandstone-shale member,
Sipit limestone member, sandstone-chert facies, and volcanic facies. The Sebatik sandstone-shale member consists of sandstone and shale layers or mudstone, siltstone, conglomerate, and coal lenses; Sipit limestone member consist of a layer of massive limestone with a thickness of more than $90 \mathrm{~m}$; sandstone-chert facies are composed of a thick layer of sandstone (greywacke) with the presence of chert and conglomerate; volcanic facies are composed of rocks of dasite, andesite, and volcanic keratophyre [1]. Stratigraphically, the base of the Kalumpang Formation is from the sandstone-chert facies; followed by volcanic facies, Sipit limestone member and Sebatik sandstone-shale member. The Kalumpang Formation sequence stratigraphic chart is shown in Figure 3.

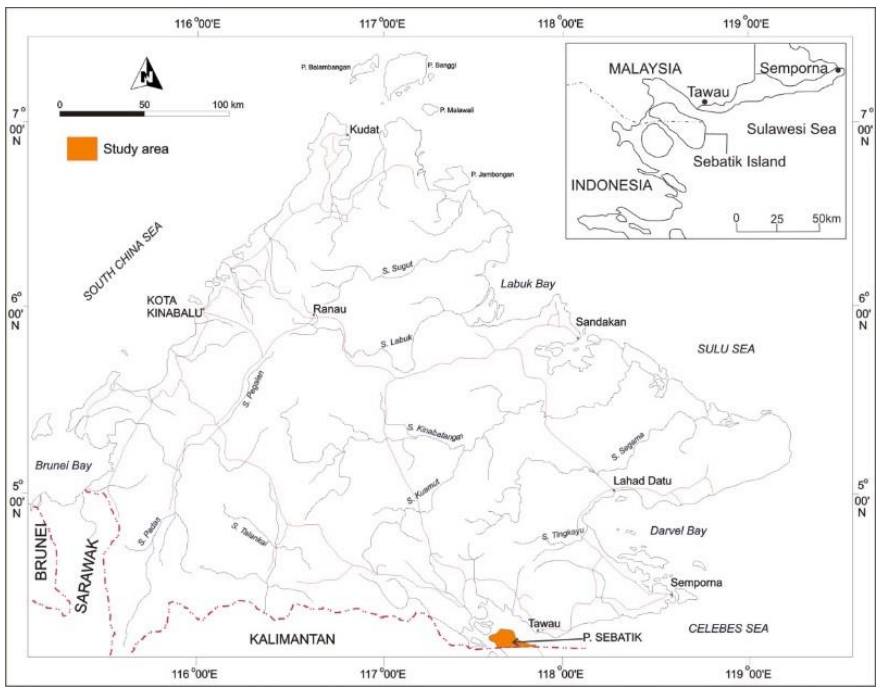

Figure 1: Location Map of the study area in the southern part of Sabah. 


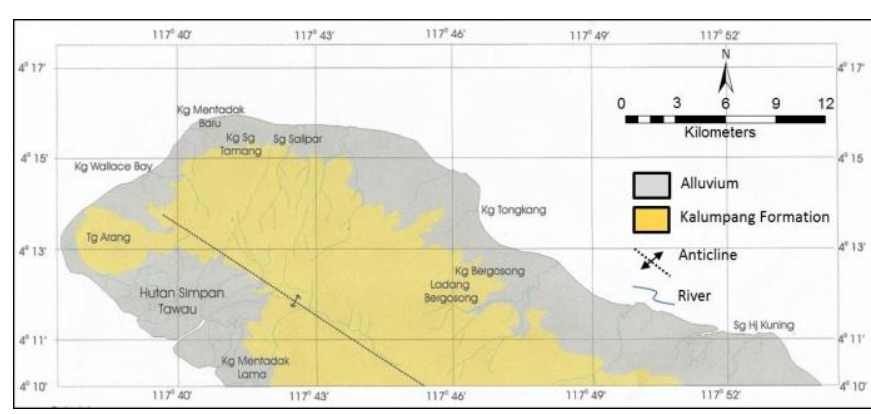

Figure 2: Geological map of Sebatik Island, Malaysia (Kirk, 1962).

\section{MATERIALS AND METHODS}

There were 72 rock outcrops that had been observed; of the number, 24 lithology logs were made on selected rock outcrops. The map of lithologic log location and observation station is presented in Figure 4. The characterization of rocks is based on the standard geological mapping methods [4,5]. The facies characterization and analysis are based on sedimentary structure parameters. The sedimentary structure is the best known for distinguishing facies types, especially in the study area [6-8]. To distinguish between one facies with another facies, the sedimentary structure differences are used such as lenticular bedding, wavy bedding and flaser bedding.
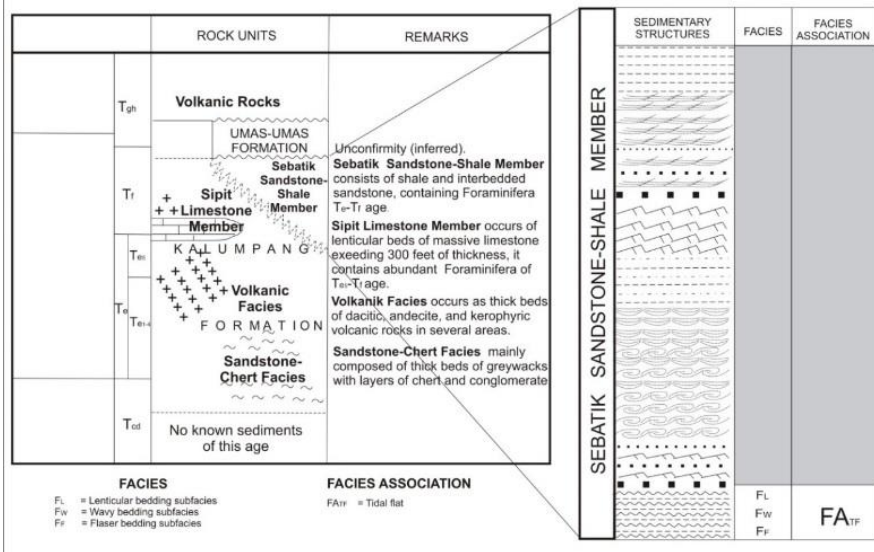

Figure 3: Sequence stratigraphic chart of the study area [1]. It can be seen that tidal flat facies association underlying the Sebatik SandstoneShale Member.

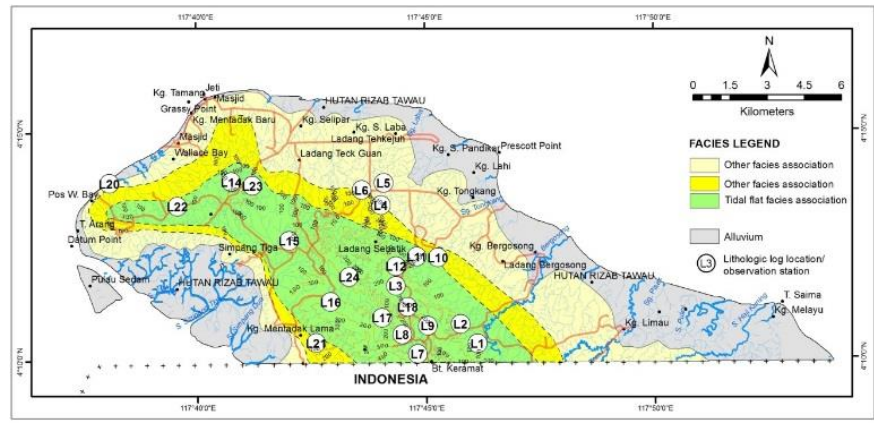

Figure 4: The lithologic log location and observation station that has been made in the study area.

\section{SEDIMENTARY FACIES}

The facies are defined as a rock unit formed in a sedimentary environment through certain processes that can be distinguished by other units vertically and horizontally through geometric properties, lithology, sedimentary structure, paleocurrent, and fossil content [8]. Field studies show that there are several facies involved in the deposition of the Sandstone-Shale Sebatik Member, one of them is heterolithic facies. The heterolithic facies are a layer of interbedded between sandstone ripple and mudstone in a single layer unit which is divided into three subfacies, based on the ratio of the content between sand and mud in the layering unit. In a sequence of rocks, if the sandstone content is more dominant, it is named as flaser $\left(\mathrm{F}_{\mathrm{F}}\right)$; if the content of sandstone and mudstone is equal or nearly equal; it is named as wavy ( $\mathrm{F}_{\mathrm{W}}$ ); if mud rock content is more dominant, it is named as a lenticular $\left(\mathrm{F}_{\mathrm{L}}\right)$. Ichnofossil found in the facies is Skolithos, Chondrites, Ophiomorpha and Thalassinoides, with the ichnofabric index II (Figure 5D). The facies thickness is up to $18 \mathrm{~m}$. Facies distribution is found to be more concentrated around the Sebatik anticline axial area, in the middle of Sebatik Island, Malaysia. Given bellow is the detailed explanation about these three subfacies.

\section{1 $\quad F_{F}$ - Flaser Bedding}

\subsubsection{Description}

The flaser bedding subfacies consists of very thinly-thickly bedded of sandstone layers, alternating with mudstone layers (Figure 5A). The sand fraction is more than $50 \%$. This subfacies attain thicknesses up to more than two metres. A feature observed in field is the occurrence of finegrained, $3-80 \mathrm{~cm}$ thick sandstone layers. The subfacies is slightly burrowed. Chondrites and Ophiomorpha are the most common ichnofossil. Common sedimentary structures are parallel lamination and cross lamination (Figure 5C). Symmetry ripple mark structure is the typical character for this subfacies (Figure 5B).

\subsubsection{Interpretation}

The flaser subfacies deposited by the presence of frequent currents before the thin layer of mud is vertically settled from suspension [9]. The presence of heterolithic facies (flaser bedding subfacies), confirming the state of the tidal influence process during fair weather [10]. This subfacies is interpreted as sand flat in the intertidal flat deposits [11].

\section{2 $\quad F_{W}$ - Wavy Bedding}

\subsubsection{Description}

The wavy bedding subfacies occur across the transition between flaser subfacies ( $<50 \%$ mud content) and lenticular subfacies $(>50 \%$ mud content), and are characterized by alternating bedload sedimentation and fallout from suspension. A feature observed in field is the occurrence of alternating $1-5 \mathrm{~cm}$ thick sandstone and mudstone layers (Figure 5A). The overall thickness of this subfacies is about $3 \mathrm{~m}$.

\subsubsection{Intepretation}

The wavy subfacies has been received mud and sand sediment through drop and drag processes with constantly and repeatedly [9]. This subfacies is interpreted as mixed flat in the intertidal flat deposits [11].

\section{3 $\quad F_{L}-$ Lenticular Bedding}

\subsubsection{Description}

The lenticular bedding subfacies consists alternating of mudstone and fine sandstone, with less than $50 \%$ sand content (Figure 5A\&E). Thickness of the sand is $2-5 \mathrm{~cm}$; with an average of $3 \mathrm{~cm}$. Common sedimentary features include parallel lamination and isolated ripples encased in mudstone (Figure 5F). Skolithos and Thalassinoides are the most abundant ichnofossils.

\subsubsection{Intepretation}

The lenticular subfacies has been received mud sediment more frequently in a calm environment before the sand deposited with the presence of current [9]. Depositional processes being dominated by the fallout of suspended sediment [12].This subfacies is interpreted as mud flat in the intertidal flat deposits [11]. 


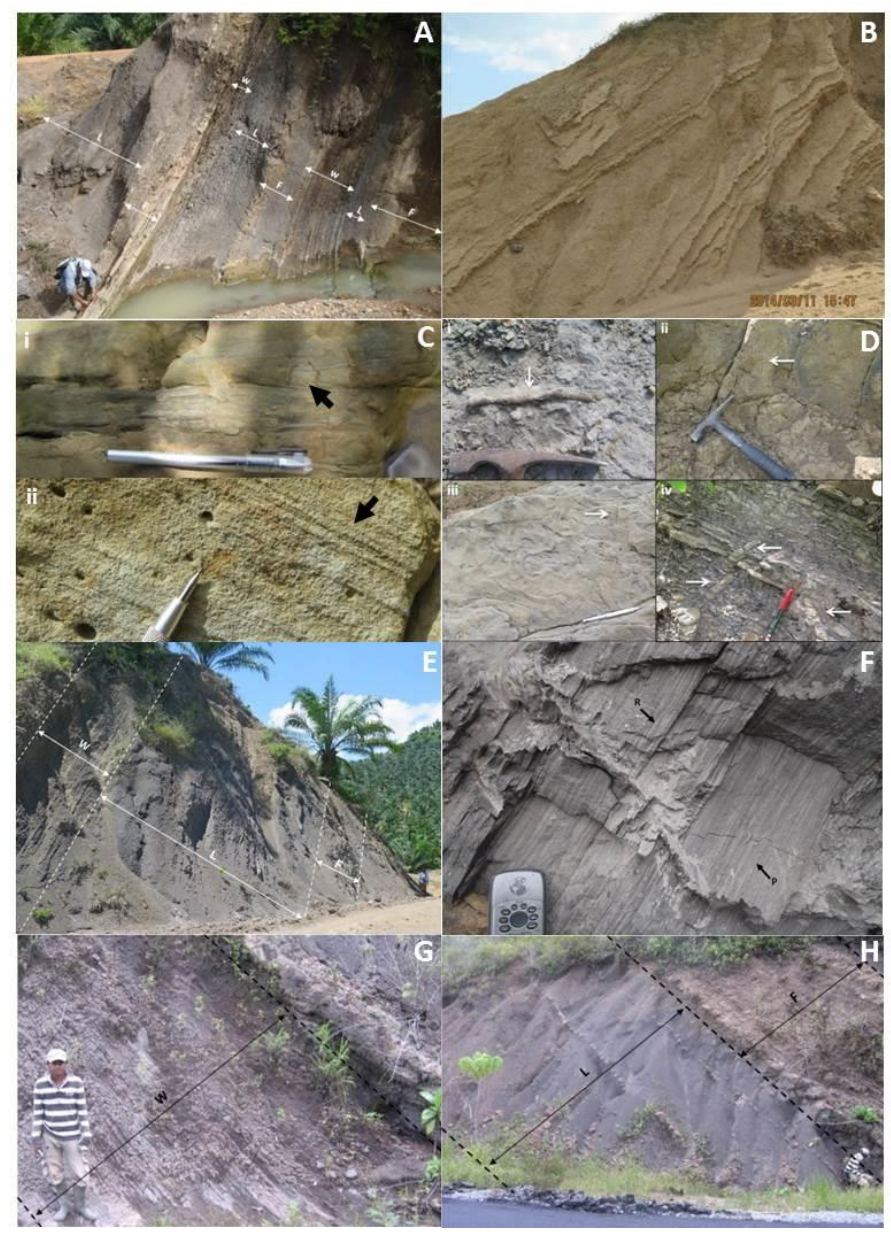

Figure 5: The selected outcrop photos that representing the heterolithic facies in the both side, Malaysia and Indonesia. [A] Alternating sucession of flaser subfacies $(\mathrm{F})$, wavy subfacies (W) and lenticular subfacies (L) at L7. [B] Ripple mark structures on the every single beds of sandstone at L23. [C] Cross-lamination (i) and parallel lamination (ii) structures at L7. [D] The ichnofossils that found in the heterolithic facies: i- Skolithos, iiChondrites, iii-Ophiomorpha, iv-Thalassinoides. [E] Thickly bedded of lenticular bedding subfacies (L) at L18. [F] Parallel lamination (P) and isolated ripples encased in mudstone $(\mathrm{R})$ at $\mathrm{L} 17$. [G] \& [H] The wavy bedding subfacies (W), lenticular bedding subfacies (L) and flaser bedding subfacies (F) from Meliat Formation near Bt. Keramat, Indonesia.

\section{FACIES ASSOCIATIONS}

\section{$5.1 \quad$ FA $_{T F}-$ Tidal Flat}

\subsubsection{Description}

The tidal flat facies association ( $\left.\mathrm{FA}_{\mathrm{TF}}\right)$ consist of heterolithic facies which are divided into three subfacies, namely: flaser $\left(\mathrm{F}_{\mathrm{F}}\right)$, wavy $\left(\mathrm{F}_{\mathrm{W}}\right)$, and lenticular $\left(\mathrm{F}_{\mathrm{L}}\right)$. These three subfacies are stretched over each other, and usually the bottom layer is a flaser, then overlapped by a wavy, followed by a lenticular; and this series of layers repeatedly; it is similar with heterolithic facies from Meliat Formation, Indonesia (Figure 5G-H) [13]. The sequence of these association forms a thinning upward sequence. The ripple unit on the sandstone layer is a diagnostic feature for the heterolithic facies, which can be used to differentiate with other rock units. The other unit are overlapping with heterolithic facies are the swaley cross-stratified, hummocky cross-stratified and the planar crossbedding. Trace fossils like Scolithos, Chondrites, Ophiomorpha and Thalassinoides are found in this association (Figure 5D). The tidal flat facies association $\left(\mathrm{FA}_{\mathrm{TF}}\right)$ are found in the middle of the study area; localities at L2, L3, L7, L8, L10, L11, L12, L14, L16, L17, L18, and L19 (Figure 2). The heterolithic facies distribution is shows in Figure 6. diagnostic of tidal deposition. The process that plays a role in the formation of these subfacies is, through alternating and continuous deposition between ripple units (sand-wavy layers) during tidal currents and the deposition of mud layers during calm water [11]. The tidal flat are located between the high tide levels and the low tide levels $[11,12]$. The heterolithic facies consist of flaser, wavy, and lenticular subfacies, formed through tidal dominated processes; generated by the gravity of the moon and the sun [11]. A group researchers divides the tidal flat profiles into three parts (the sequence to the mainland), namely: sand tidal flat, mixed tidal flat, and mud tidal flat with sizes range $4 \mathrm{~m}[11,12]$. The more towards the mainland; energy is decreasing. The sandstone and mudstone layers with the presence of mudstone drapes are an indication of the influence of tidal during deposition. The fining-upward and thinning-upward are indicators of the tidal flat [14]. Therefore, the tidal flat association is interpreted to form in the tidal flat, specifically intertidal (between supratidal and subtidal) flat, in shoreline environment.

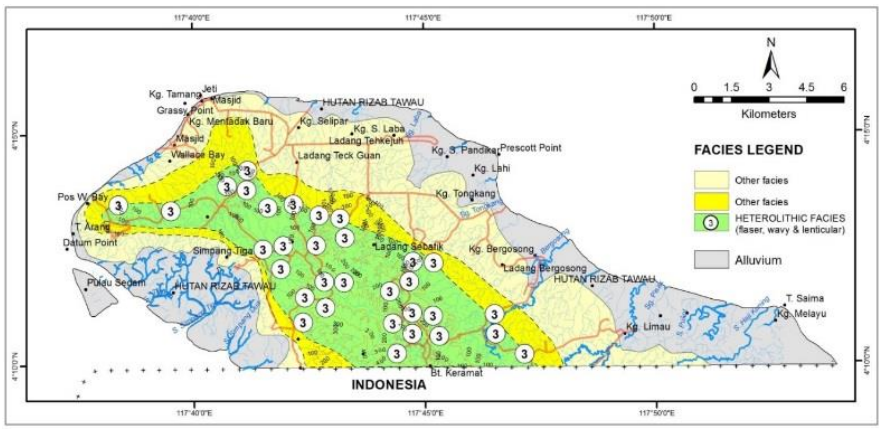

Figure 6: Heterolithic facies distribution on the facies map of the study area.

\section{DEPOSITIONAL MODEL}

The facies association of the tidal flate is the heterolithic facies comprising three subfacies combinations, namely: Flaser bedding $\left(\mathrm{F}_{\mathrm{F}}\right)$, Wavy bedding $\left(\mathrm{FW}_{\mathrm{W}}\right.$ ), and lenticular bedding (FL). This facies association are widely encountered and observed in the field, particularly in the vicinity of the Sebatik anticline axis. This association facies clearly indicates the deposition of shoreline deposition dominated by tidal influences. A lithological log-based correlation was made to connect the three subfacies (Figure 7A); surprisingly, the tidal flat association facies can correlated too with rocks unit from Meliat Formation, Indonesia (Figure 7B). What has been found is that these subfacies are deposition episodes that form a part of the Sebatik Island lithostratigraphy, as it is today. The depositional episodes are initiated by flaser bedding subfacies; which is then followed by younger subfacies - Wavy bedding and lenticular bedding. Figure 8 shows the depositional model of the study area.

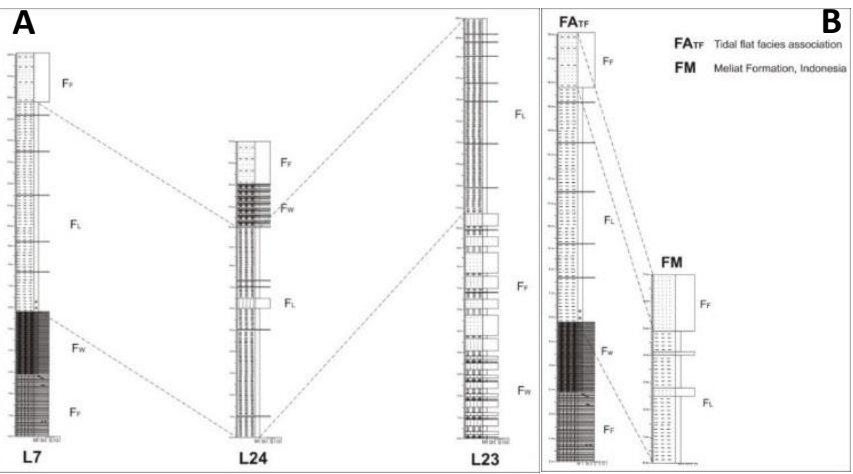

Figure 7: (A) Correlation of lithological logs from different locations shows the existence of three subfacies ( $\mathrm{F}_{\mathrm{F}}$ - flaser bedding, $\mathrm{F}_{\mathrm{W}}$ - wavy bedding, $\mathrm{F}_{\mathrm{L}}$ - lenticular bedding) and their relationship. (B) Lithologic log correlation between Tidal Flat Facies Association from Malaysia and heterolithic facies from Meliat Formation, Indonesia.

\subsubsection{Interpretation}

The periodic changes in current speed and direction which characterize tidal systems produce several sedimentary structures which are 


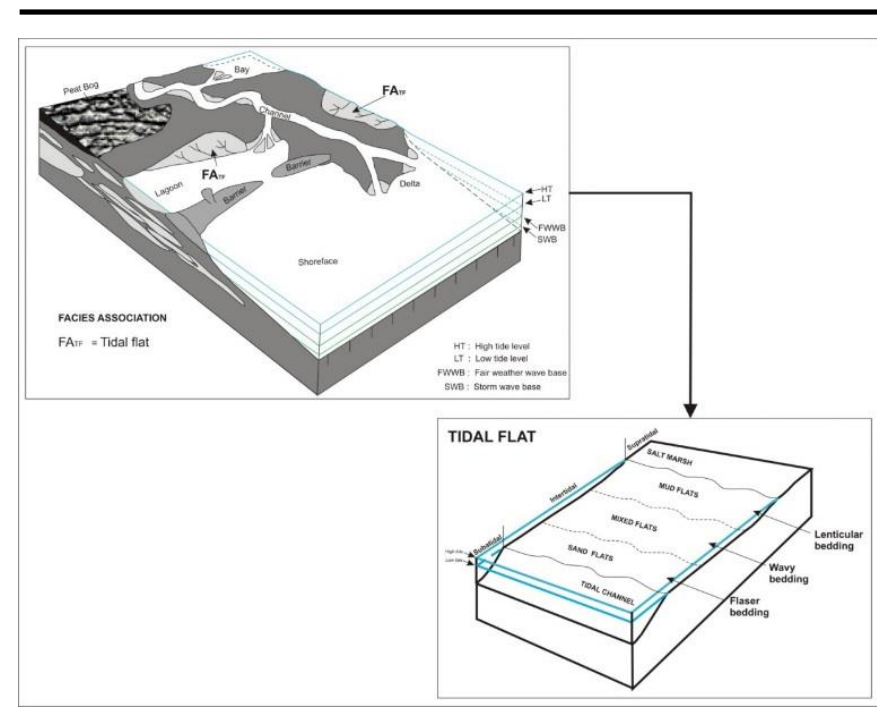

Figure 8: Conceptual depositional model of the study area incorporating all the three discussed subfacies successions $[11,15]$

\section{CONCLUSIONS}

The facies analysis study in the study area was initiated by characterizing rock units in the field based on the predetermined methodology. A total of six rock units have been identified, namely: sandstone, shale, mudstone, siltstone, conglomerate and coal. Based on detailed observations using sedimentary structure parameter to the six rock units, several facies have been found and one of them is the heterolithic facies which is divided into three subfacies; flaser, wavy and lenticular bedding. The processes involved of these subfacies are through tides of sea water. All subfacies are assembled and connected as tidal flat association. Specified of the association facies describe the depositional environment involved. The tidal flat association facies representing a shoreline environment dominated by the tidal processes.

\section{ACKNOWLEDGEMENTS}

We are grateful to Public Service Department (JPA) and Department of Mineral and Geoscience Malaysia (JMG) for funding the MSc. studies of Muhammad Umar Sarimal under the Federal Training Award (HLP) and providing financial and logistical supports in the field. Finally, permission by the management of Science and Natural Resources Faculty (FSSA), UMS to publish this article is gratefully acknowledged.

\section{REFERENCES}

[1] Kirk, H.J.C. 1962. The geology and Mineral Resources of the Semporna Peninsula North Borneo. Memoir 14, Geological Survey Department British Territories in Borneo.
[2] Asis, J., Jasin, B. 2015. Miocene Larger Benthic Foraminifera from the Kalumpang Formation in Tawau, Sabah. Sains Malaysiana, 44 (10), 1397 1405.

[3] Rangin, C., Bellon, H., Benard, F., Letouzey, J., Muller, C., Sanudin, T. 1989. Neogene arc-continent collision in Sabah, Northern Borneo (Malaysia). Elsevier Science Publishers B.V., Amsterdam. Tectonophysics, 183, 305-319.

[4] Barnes, J.W. 1981. Basic Geological Mapping. New York: John Wiley and Sons Inc.

[5] JMG (Jabatan Mineral \& Geosains Malaysia). 2010. Garis Panduan Pemetaan Geologi. JMG.GP.10. Kementerian Sumber Asli \& Alam Sekitar Malaysia.

[6] Selly, R.C. 1985. Ancient Sedimentary Environments and Their SubSurface Diagnosis. $3^{\text {rd }}$ Edition. English Language Book Society (ELBS), Chapman and Hall Ltd.: London, pp. 1-37.

[7] Tucker, M.E. 2003. Sedimentary Rocks in the Field. 3rd Edition. West Sussex: John Wiley \& Sons Ltd, pp. 84-162.

[8] Tahir, S., Musta, B. 2007. Pengenalan kepada Stratigrafi. Universiti Malaysia Sabah. Kota Kinabalu, Sabah, pp. 87-110.

[9] Roslan, M.H.K., Ali, C.A., Mohamed, K.R. 2016. Fasies dan Sekitaran Sedimen Formasi Singa di Langkawi, Malaysia. Sains Malaysiana, 45 (12), 1897-1904.

[10] Abd Rahman, M.N.I., Tahir, S.H. 2017. Wave-dominated Shoreline Deposits in the Late Miocene Sedimentary Sequence in the Miri Formation North Sarawak, Malaysia. Geological Behavior, 1(2), 14-19.

[11] Dalrymple R.W. 1992. Tide Depositional Systems. In: Walker, R.G. \& James, N.P., Facies Models Response to Sea Level Change. Geological Association of Canada, pp. 195-218.

[12] Desjardins, P.R., Buatois, L.A., Mangano, M.G. 2012. Tidal Flats and Subtidal Sand Bodies. Chapter 18 in Developments in Sedimentology. ResearchGate, pp. 569-561.

[13] Hidayat S., Amiruddin, Satrisnas, D. 2011. $2^{\text {nd }}$ printed. Geological Map of the Tarakan and Sebatik Sheet, Kalimantan. Center for Geological Survey, Geological Agency, Indonesia.

[14] Buatois, L.A., Santiago, N., Herrera, M., Plink-Bjorland, P., Steel, R., Espin, M., Parra, K. 2012. Sedimentological and Ichnological Signatures of Changes in Wave, River and Tidal Influence Along a Neogene Tropical Deltaic Shoreline. Journal of the International Association of Sedimentologist (IAS). Sedimentology, 59, 1568-1612.

[15] Kedzior, A., Ski, R.G, Doktor, M., Gmur, D. 2007. Sedimentary history of a Mississippian to Pennsylvanian coal-bearing succession: an example from the Upper Silesia Coal Basin, Poland. Geological Magazine, 144 (3), 487-496. Cambridge University Press. United Kingdom. 